\title{
Reform in Mexican Higher Education: An Overview of the 1990s
}

\section{Rollin Kent}

Rollin Kent is professor in the Departamento de Investigaciones Educativas, Centro de Investigaciones y Estudios Avanzados, Mexico. E-mail: <rkent@gemtel.com.mx>.

$\mathrm{T}$ he current decade has been a period of expansion and reform in Mexican higher education. The issues and the content of public discourse surrounding higher education today reflect the great change in public perceptions. Ten years ago, tertiary education was seen as stricken with paralysis, underfunded, and lacking in public prestige. Today, the debate is informed by the modernization of higher education, its contribution to economic development, and a greater emphasis on quality over access. The structure and dynamics of the higher education system have certainly changed, as private-sector institutions make themselves felt, competing with the hitherto "protected" public universities. The texture of higher education politics is also different: opposition and progressive politics previously emanating from public universities, usually under the guise of student movements and union activisms, have clearly receded, and erstwhile university leaders have moved on to another political stage at the national level, in congressional and national party politics. Today, greater political pluralism has placed a new breed of center-right politicians in power in local government, often upsetting the long-standing political balance between universities and the old political establishment.

\section{Systemic Changes}

Higher education entered a new period of growth in the 1990s, after almost a decade of stagnation in enrollments. Between 1990 and 1997, total enrollments grew by 50 percent in seven years, with the private sector growing at a faster rate than the public sector and access for women increasing steadily. Rising individual returns provided by higher education diplomas have surely stimulated this demand. In the public sector, traditionally the largest in Mexican higher education, universities have stopped growing, while technical colleges (both the older four-year and the newer two-year programs) have grown very significantly, reaching almost 30 percent of national enrollments. The overall picture is one of rapid expansion and, most especially, new trends in institutional differentiation, thus producing a setting of greater competition among institutions. Having reached a parity with men, women now have a significant presence in higher education. This is as yet a poorly understood factor of change and will surely bring about further changes in the near future, both in higher education and within the professions at large.

Graduate studies are today the most important growth sector in Mexican higher education. Total enrollments in master's and doctoral programs went from 46,000 in 1990 to 123,000 in 1998 . This increase of 167 pecent over a seven-year period is sure to continue over the coming decade, as the academic labor market continues upgrading and government funds for research and development sustain a demand for highly trained academics. Master's programs have become very attractive to private institutions, which seem to have found a profitable niche in offering midcareer professionals a means of upgrading their skills and knowledge.

\section{The Mexican academic profession has experienced important changes in three basic aspects: growth, upgrading, and evaluation.}

\section{The Academic Profession}

In this context, the Mexican academic profession has experienced important changes in three basic aspects: growth, upgrading, and evaluation. The total number of academics went from 86,188 in 1990 to 153,044 seven years later, a growth of 78 percent. Academics hired by the private sector grew by 92 percent, although most of them are hired on a part-time basis. Full-time academics in the public institutions grew by 81 percent, representing a significant new investment in full-time, tenured positions and a trend toward greater professionalism in academia. Expansion of the academic labor market was accompanied by a strong push for upgrading: the number of $\mathrm{Ph} . \mathrm{Ds}$ awarded doubled and the number of academics with master's degrees grew by 80 percent, although the proportion of professors holding only the first undergraduate degree is still high, down only slightly from 71 to 69 percent. Nevertheless, the Ph.D. is becoming the standard requirement for hiring new professors and for promotions. Graduate programs have become the principle market for new Ph.Ds. In stark contrast to the 1980s and previously, most professors today are evaluated by their institutions, through a diverse array of instruments-mostly focused on efficiency and "productivity" (i.e., measurement of publications and classroom-hours) but lacking a qualitative evaluation of teaching and learning outcomes. In many institutions, both public and private, assessment data are now used in hiring and promotion decisions.

Other Dimensions of Reform

Without a doubt, the federal government has had a major 
role in promoting significant changes in policy, the most notable being in funding. There has been an increase in federal expenditures for higher education throughout the 1990s (not including unreported expenditures by state governments and the private sector). Federal expenditures have probably reached a ceiling at around 0.65 percent of GDP and will likely not continue growing in the future, which will set the stage for greater demands for private expenditures in both public and private establishments.

Evaluation-another federal program-is now widespread, but often poorly designed or focused and underutilized in decision making. Many procedures have been put in place, although most of them involve assessing the productivity of academics; rarely is the effectiveness of teaching actually assessed. Outcomes assessment is still on the drawing board, although professional certifying examinations are being designed for graduates in a number of professional fields.

The federal policy for evaluation and increased, but conditional, funding has had an impact on management cultures and structures in many public and private universities. Efficiency, professional information management, and inputs from evaluation systems are all buzzwords in higher education management today. However, there is considerable evidence that some distortions have emerged, in that the administrative superstructures of universities are becoming overdeveloped (and perhaps even more inefficient), while intermediate management is mostly formal and lacking real influence over academic work; at the same time, academic organization in the basic work units continues to be atomized and uncoordinated.
Curriculum reform was on the agenda, and many institutions have reported changes in their curricular offerings. But upon closer examination, greater institutional diversification and reports of curriculum reforms do not appear to have led to modifications in the old paradigm of specialized undergraduate instruction leading to professional degrees with no lateral exits, credit transfers, or more general programs allowed. Very little is being done in the way of flexible course offerings, interdisciplinary and problem-oriented programs, and the development of basic skills.

\section{Persisting Problems with Equity}

As a recent OECD report on Mexican higher education points out, elite training is doing fine. The offspring of the upper classes have fled to the private sector and are doing what they want and doing it successfully. The same is true for graduate programs and research: the upper reaches of the system are prospering and improving their quality and diversity. The problem continues to be at the middle and lower levels, in the programs offered to poor students, working-class, part-time students, and many secondary school leavers in provinces with no high-quality tertiarylevel offerings. Thus, the average level of quality of Mexican higher education is still in question. A crucial issue facing Mexican higher education is whether the means will be found to extend higher-level instruction of quality beyond the elites to the masses.

Editor's Note: This article was written before the April 1999 UNAM student strike in response to the introduction of proposed student fees.

\section{Second-Generation Reforms in Chile}

\section{Andrés Bernasconi}

Andrés Bernasconi served as director of studies of the Consejo superior de educación in Chile. He is now program coordinator for Latin American programs at Harvard University Graduate School of Education. Address: 339 Gutman Library, Cambridge, MA 02138, USA. E-Mail: <bernasan@gse.harvard.edu>.

$\mathrm{C}$ hile has recently committed U.S.\$241 million over the next five years to launch its second wave of higher education reforms in two decades. The new policy package, supported by the World Bank, builds upon the reforms of the early 1980s, furthering transformations that proved successful, fixing what failed to achieve its intended results, and adding new dimensions to the reform effort. This case of second-wave reforms, unique in Latin America, can provide something of the benefit of hindsight to countries in the region now embarking on first-generation transformations.
What I call here first-generation reforms are those crystallized in the "Washington consensus" of the multilateral donor institutions, and advocated by reformers everywhere in Latin America. ${ }^{1}$ The reform program includes:

- cost recovery in public universities through tuition fees and diversification of funding sources (presently, most Latin American public universities are free to everyone, regardless of socioeconomic status);

- government funding sensitive to institutional performance;

- rewards for good faculty performance and disincentives against mediocre work, as opposed to the senioritybased rule of homologación or isonomia, prevalent in the region's public institutions, which requires everybody to be paid the same regardless of academic productivity;

- evaluation systems aimed at fostering accountability and improving quality;

- strengthening of vocational training;

- institutional diversification (i.e., diverse types of institutions serving different educational missions); and

- privatization, both in the sense of allowing for private 